\title{
Health of nations: lessons from Victoria, Australia
}

\author{
John W Powles, Sandra Gifford
}

\begin{abstract}
Summary
In its white paper The Health of the Nation the government has announced its intention to give more priority to preventive health care. Two examples from Victoria, Australia, show how coordinated legislative and voluntary sector action can have a substantial impact on public behaviour. The introduction and enforcement of strict drink-driving laws and speed limits backed up by forceful television advertisements produced a large reduction in deaths from road traffic accidents, the death rate in relation to the number of vehicles in 1991 being among the lowest in the world. Smoking has also declined in parallel with a phased ban on advertising and use of taxes from tobacco sales to replace tobacco sponsorship of sports and arts and fund health promotion.
\end{abstract}

From 1920 to 1970 death rates in Australian middle aged men stayed roughly constant as new killers replaced old. But since 1970 mortality in this group has fallen by $40 \%{ }^{1}$ With life expectancy now 73.9 years for men and 80.0 years for women, ${ }^{2}$ Australia has regained the favourable longevity ranking it enjoyed early in the century.

Australia is notable not only for the size of its rise and fall in deaths from chronic disease and injury but also for the strength of its institutional revolution in public health. This revolution has a special relevance to the current British debate on the health of the nation. ${ }^{34} \mathrm{We}$ illustrate here some distinctive features of Australia's public health revolution by reference to the control of road traffic injuries and of cigarette smoking in the state of Victoria (population 4.4 million, $70 \%$ in Melbourne).

\section{Control of traffic injury}

Deaths from traffic accidents are a function of exposure and risk per unit exposure, with the latter falling as vehicle density rises (Smeed's Law': deaths per vehicle per year $=0.0003 \times($ vehicles $/$ population)- ${ }^{0.66}$ ). In the 1960 s Victoria's road death rate was $30-40 \%$ above Smeed's prediction and rates per unit population were among the highest in the world. In December 1970 Victoria led the world in making the wearing of seat belts, where fitted, compulsory. ${ }^{6}$ In the same year it established a statutory authority with responsibility for road safety and traffic management, with board representation from three state agencies (police, roads, planning), local government, and four non-governmental organisations (autoclubs, College of Surgeons, automotive industries, and trade unions). In 1973 the speed limit was reduced to $60 \mathrm{mph}(100 \mathrm{kph}$ in 1974) and compulsory blood alcohol testing was introduced for accident victims admitted to hospital. Random breath testing was introduced in July 1976 (limit $0.5 \mathrm{~g} / \mathrm{l}$ blood) and mandatory periods of licence suspension depending on blood alcohol concentration in 1978. In December 1986 the permissible concentration of alcohol was set at zero for the first two years of driving. In July 1989 wearing helmets was made mandatory for pedal cyclists. The development and passage of legislation was aided throughout by the location of the Victoria state parliament in the state's one major centre of population and by an effective and

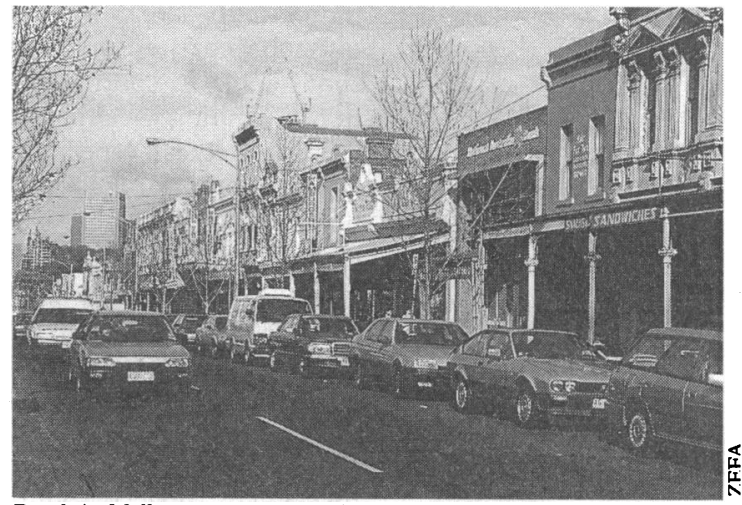

Roads in Melbourne are among the safest in the world

well advised all party parliamentary road safety committee that drafted the legislation and minimised partisan divisions.

Death rates fell steadily through the 1970 s then levelled out and began to rise again in the '80s. An intensive new campaign was begun in December 1989, which was extremely effective. The $£ 2.5$ million ( $\$$ A5.5 million) mass media campaign had two themes - "Don't fool yourself, speed kills" and "If you drink, then drive, you're a bloody idiot." Five 60 second television advertisements were designed to be shocking and fully realistic. Actual hospital emergency staff were used: the aim was to convince each viewer that "it could be me." Police surveillance by automatic cameras and mobile "booze buses" was greatly intensified (rates per million population per year: 1230000 photographic speed checks (92775 infringement notices), 304000 random breath tests (18036 infringement notices)). ${ }^{7}$ Speed camera records showed about $11 \%$ of drivers exceeding the speed limit in July 1990 compared with over $20 \%$ before the campaign. The proportion of people killed who had blood alcohol concentrations above the limit also fell. ${ }^{8}$

Deaths per 10000 vehicles fell from 3.0 to $2 \cdot 1$ in 1990 and 1.9 in $1991^{8}$ ( $<50 \%$ of Smeed's prediction); the mortality is now well below that in Britain $(2.3$ in 1989), which has one of the lowest rates in Europe. ${ }^{9}$ It took Victoria just two decades to climb virtually the full length of the international road safety league table and it did so by actively engaging many organised elements of society.

Road crashes are expensive and preventing them saves money-by one estimate, over $£ 100$ million in Victoria in $1990 .^{10}$ For the Transport Accident Commission, one year's savings from reduced injury claims was many times its outlay of $£ 2 \cdot 3$ million for the campaign.

\section{Reducing smoking}

In 1980 rates of smoking were increasing in Australian young adult women. The tobacco industry was purchasing powerful political constituencies by sponsorship: not only individuals but also sporting and cultural organisations were dependent on tobacco.

In November 1987 the Victorian parliament passed a Tobacco Act that tipped the balance in favour of the antismoking forces and multiplied the funds available
Correspondence to: Dr Powles. 
for public health generally. The act banned advertising outdoors and in cinemas; banned give aways, sales in small packs, and related promotions; raised the tax on tobacco by $5 \%$; and allocated all the proceeds to an independent statutory trust known as the Victorian Health Promotion Foundation.

The board of the foundation is chaired by a leading medical scientist and includes business, sporting, cultural, and political leaders. It has a budget of about $£ 12.8$ million ( $£ 2.90$ per state resident) per year and is required to spend this in three main areas: buying out tobacco sponsorship and initiating public health sponsorship in sports, arts, and community organisations; funding health promotion programmes; and funding medical, especially public health, research.

The content of the act and its successful passage can be accounted for only by the sustained and effective political activity of the Anti-Cancer Council of Victoria, one of the two wealthiest, and probably the best organised, health charity in Australia. Between February and October 1987 the director of the council, Dr. Nigel Gray, liaised closely with the minister and shadow minister of health. What began with a sympathetic ministerial response to a proposed tax funded buy out of tobacco sponsorship was strengthened by support from the council's 140000 donors and from the medical and scientific communities, and ended with the creation of the Victorian Health Promotion Foundation. " In 1990-1, the foundation was able to sponsor 128 sporting and 134 cultural organisations, fund 125 health promotion projects, and fund 74 medical, mostly public health, research and training activities. ${ }^{12}$

The antismoking campaigns are run by Quit, a body established jointly by the Victoria health department, the Anti-Cancer Council, and the National Heart Foundation in 1985. Its sponsorship programmes have been developed from commercial precedents and in 1991 included a major league Australian football team, several other football organisations, two national basketball teams, some mass participation sports, and even a drama group. ${ }^{12}$ Conspicuous support for sporting and other activities has contributed to the rising public approval of the Quit campaign and of antismoking measures generally.

In early 1991 after the Australian Federal Court found the Tobacco Institute of Australia guilty of publishing misleading information about the health effects of passive smoking, Quit wrote to 175000 organisations informing them of the decision and inviting them to participate in its workplace campaign. By September 1991, 78\% of Victorians were working in environments where smoking was restricted or banned (unpublished data, Centre for Behavioural Research in Cancer, Australia).

Between 1983 and 1989 the prevalence of tobacco smoking in Australian men fell from over $40 \%$ to around $30 \%{ }^{13}$-around twice the recent rate of fall in cigarette smoking in British men. ${ }^{14}$ Smoking prevalence data for 1991 in Victoria are encouraging-27.3\% for men and $24 \%$ for women. ${ }^{15}$ The recent reductions in Victoria have been as great among blue collar workers ${ }^{16}$ (who watch $38 \%$ more commercial television: M Scollo, Victorian smoking and health programme, personal communication) as among white collar workers. Rates of smoking in adolescents have been falling in Australia (figure) ${ }^{17}$ in contrast to their relative stability in Britain. ${ }^{18}$ Australian studies confirm the effectiveness of campaigns to reduce smoking with major mass media components; the Victorian Health Promotion Foundation has made it possible for Quit to afford such components. ${ }^{120}$ Programmes are now being directed towards preventing relapse in a smoking population that is increasingly composed of people who have tried several times to stop: among smokers
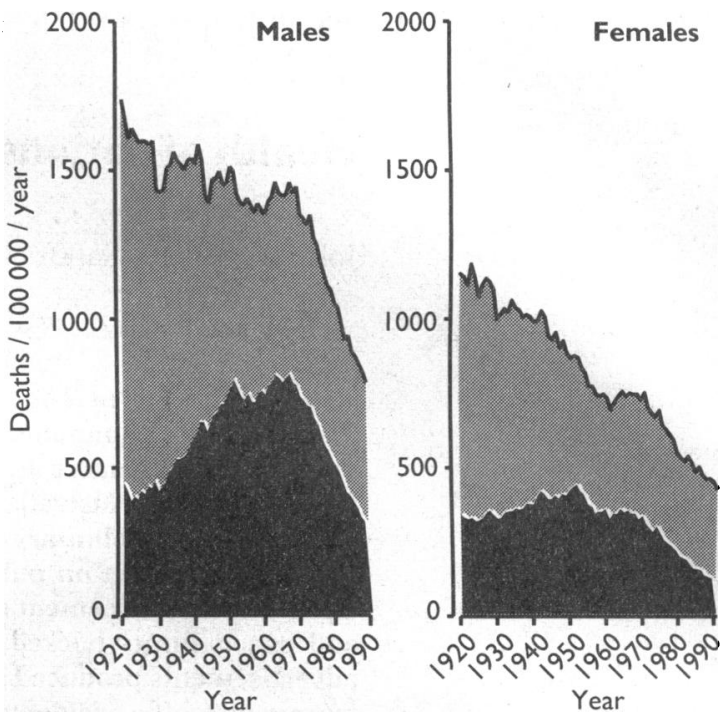

Age standardised rates of deaths from all causes and deaths attributed to diseases of circulatory system for adults aged 45-64, Melbourne, 1921 to 1990. Source: Australian Institute of Health

surveyed in $1990,42 \%$ reported having tried to stop in the previous year (unpublished data, Centre for Behavioural Research in Cancer). Guided by its recent experience Quit has set as medium term goals adult smoking prevalences of $22 \%$ in 1994 and $18 \%$ in $1997^{21}$ - compared with the British government's goal in The Health of the Nation of $20 \%$ in $2000 .^{4}$

The Victorian model has spread to other states. Tobacco advertising and sport sponsorship are due to be banned nationally. Federal and state health ministers have agreed on regulations requiring that, from July 1993, half the surface area of cigarette packs is to contain explicit and detailed health information, including a free of charge "quit line" telephone number. A proposal to require plain generic packaging for all cigarettes, which the Victorian Anti-Cancer Council's Centre for Behavioural Research has shown makes them less attractive to adolescents, has been deferred for a year..$^{22}$

\section{Conclusion}

Through creative and complex interactions between voluntary and state agencies, new processes and institutions have emerged in Australia to foster health favouring change within an active civil society. It has not just been a question of choosing between state action and individual responsibility, but rather of finding the means to link the two effectively.

If the reality of a public health revolution in Australia is accepted, to what extent can the dramatic reductions in mortality since the 1960 s be attributed to it? There is no defensible basis for a global answer to this question. But partial answers can be defended. In the case of traffic injuries, the temporal proximity of putative causes and their effects strongly suggests that a large part of the fall in mortality from this cause is attributable to centrally coordinated action. In the case of trends in tobacco smoking (and by implication of trends in the diseases to which it contributes) the sum of Australian experience supports the view that centrally coordinated action that is adequately funded and deliberately built on broad based support can speed the fall in smoking prevalence. ${ }^{23}$ However, three quarters of the fall in total mortality since 1970 has come from a reduction in deaths attributed to diseases of the circulatory system (figure). On this larger canvas uncertainties abound, and there is scope for contributions from changes in the Australian way of life that were not primarily adopted for health reasons. Postwar migration policy, for example, brought large numbers 
of Greeks and Italians to Australia and their presence has done much to encourage the widespread adoption of putatively low risk Mediterranean diets.

Victoria may yet have lessons for its British parent. Both share the tradition of a strong voluntary sector which, in Victoria, has found expression in health charities as determined to apply existing knowledge for prevention as to support the development of the new. But they, and many other organisations throughout society, also have the benefit of strongly supportive national policies and of state guaranteed funds on a scale that is not entirely incommensurate with the task of changing health determining habits: for a population the size of England's, the total yearly Victorian Health Promotion Foundation's budget is equivalent to around $£ 140$ million, and much of it goes to the voluntary sector. In England $£ 0.25$ million has been allocated in 1992 to fund preliminary voluntary sector work in support of the Health of the Nation initiative. ${ }^{4}$

1 d'Espaignet ET, van Ommeren M, Taylor F, Briscoe N, Pentony P. Trends in Australian mortality 1921-1988. Canberra: Australian Government PubAustralian mortality $1921-1988$. Canberra: Austral
lishing Service, 1991 : table 2 . (Mortality series 1.)

2 Australian Institute of Health and Welfare. Australia's health 1992. Canberra: Australian Government Publishing Service, 1992.

Australian Government Publishing Service, 1992.
Smith R, ed. The health of the nation: the BMf view. London: BMA, 1991.

3 Smith R, ed. The health of the nation: the BMf view. London: BMA, 1991 . England. London: HMSO, 1992. (Cm 1986.)

5 Smeed RJ. The usefulness of formulae in traffic engineering and road safety. Accident Analysis and Prevention 1972;4:303-12.

6 Hawthorne G. Personal transport in Australian society. Part 5. Road trauma. Melbourne: Transport Accident Commission, 1991.
7 Bruce D. Road blitz aims for record low toll. Age (Melbourne) 1991 September

8 Vic Roads, Road Information Services. Road traffic accidents involving serious casualties Victoria, 1991. Melbourne: Vic Roads, 1992.

9 Department of Transport. Transport statistics Great Britain, 1991. London: HMSO, 1991:258.

10 Harper G. Social advertising: TAC Road Safety Campaign. Melbourne: Grey Advertising, 1991.

11 Raw M, White P, McNeill A. Clearing the air: a guide to action on tobacco. London: British Medical Association 1990:59-69.

12 Victorian Health Promotion Foundation. Annual Report, 1991. Victoria: VHPF, 1991.

13 Hill DJ, White VM, Gray NJ. Australian patterns of tobacco smoking in 1989 Med I Aust 1991;154:800.

14 Office of Population Censuses and Surveys. General Household Survey 1990. London: HMSO, 1992:113-37. (GHS No 21.)

15 Mullins R, Borland R, Hill D. Smoking knowledge, attitudes and behaviour in Victoria: results from the 1990 and 1991 household surveys. Melbourne: Victorian Smoking and Health Program (Quit), in press. (Quit Evaluation Studies No 6.)

16 Macaskill P, Pierce JP, Simpson JM, Lyle DM. Mass media-led antismoking campaign can remove the education gap in quitting behaviour. Am I Public Health 1992;82:96-8.

17 Hill DJ, White VM, Williams RM, Gardner GJ. Tobacco and alcohol use among Australian secondary schoolchildren in 1990. Med $\mathcal{F}$ Aust (in press).

18 Lader D, Matheson J. Smoking among secondary school children in 1990: an enquiry carried out by Social Survey Division of OPCS on behalf of the Department of Health, the Welsh Office, and the Scottish Office Home and Health. London: HMSO, 1991

19 Egger G, Fitzgerald W, Frape G, Monaem A, Rubinstein P, Tyler C, et al. Results of large scale media antismoking campaign in Australia: North Coas "Quit for Life" programme. BMF 1983;287:1 125-8.

20 Pierce JP, Macaskill P, Hill D. Long term effectiveness of mass media-led antismoking campaigns in Australia. Am f Public Health 1990;80:565-9.

21 Stone D. Quit's new plan to kill the habit. Sunday Age (Melbourne), 1992 May $31: 6$

22 Maley K, Boson M. Killer smoke warnings: plain packets may be next step. Sydney: Morming Herald 1992 April 16:2.

23 Australian Bureau of Statistics. 1989/90 National Health Survey, Summan of Results. Canberra: Australian Bureau of Statistics, 1991: Table 32 (extension).

(Accepted 20 October 1992)

\section{Medical Education}

\section{Teaching the teachers}

\section{Stella Lowry}

This is the sixth in a series of articles examining the problems in medical education and their possible solutions

British Medical Journal, London WC1H 9JR Stella Lowry, assistant editor
No proper review of an education system should ignore the role of the teachers. But in medical education the teachers are not easy to define. Many current debates about the future of medical education are going on among small groups of specialists, with no input from the vast majority of people who do the actual teaching. Many of the discussions are couched in educational jargon that effectively excludes many "jobbing doctors" who do so much of the teaching.

Medical teachers in Britain may be divided into three main groups: a tiny minority who are trained in educational theory and methods (who often are not medically qualified themselves), staff holding official "teaching" appointments but without formal teacher training, and NHS doctors who teach (in effect, most NHS doctors). Very few medical teachers have had any formal training in teaching methods or educational theory, but in this respect medicine is little different from most university courses in Britain. Medicine differs from many other professions, however, in the huge amount of teaching expected from all of its practitioners. This principle is enshrined in the Hippocratic oath (box) and emphasised in the new contracts for NHS consultants, all of which incorporate a teaching commitment.

\section{Can anyone teach?}

This tradition that teaching is part of being a doctor rather assumes that everyone can and should teach. It is not an attitude that would carry much weight in other educational circles, but it is easy to see its roots in the traditions of apprenticeship to a trade. The medical adage "See one, do one, teach one" is perilously close to
"I swear by Apollo the physician... that by precept, lecture, and every other mode of instruction, I will impart a knowledge of the Art to my own sons, and those of my teachers, and to disciples bound by a stipulation and oath according to the law of medicine...."

-Hippocratic oath

the mark, but Dr Jolyon Oxley, from the Standing Committee on Postgraduate Medical Education, thinks that such a system has some merits. In medical education there is a potential conflict between the desire to provide a broad educational experience and the need to ensure a technical training in how to be a doctor. Dr Oxley emphasises that the technical aspects are best taught by the people who do the actual job"learning at the master's knee."

But there is growing consensus that the broader functions of a medical education, which are assuming greater importance in the undergraduate curriculum, ${ }^{2}$ are not so easy to learn from someone untrained in educational method. The Committee of Vice Chancellors and Principals of the Universities of the United Kingdom has recently called for more training in educational methods for all university teachers. ${ }^{3}$ A national inquiry into the problems in medical education organised by the King's Fund identified the need for "professional expertise in curriculum development, teaching methods, and assessment" and for opportunities to be provided for regular training of academic staff, ${ }^{4}$ and Professor Ron Harden and colleagues, of the Centre for Medical Education at the University of 